\section{Benedito Nunes e a moderna crítica literária brasileira (1946-1969)}

\author{
Maria de Fátima do Nascimento \\ mafana@ufpa.br \\ Tese de Doutorado \\ Programa de Pós-Graduação em Teoria e História Literária \\ Universidade Estadual de Campinas \\ Campinas (SP) 2012
}

\section{Benedito Nunes and the Modern Brazilian Literary Criticism (1946-1969)}

\author{
Maria de Fátima do Nascimento \\ mafana@ufpa.br \\ Doctoral Thesis \\ Post-Graduate Program in Literary Theory and History \\ State University of Campinas \\ Campinas (São Paulo) - Brazil 2012
}

presente estudo sobre a crítica literária de Benedito Nunes, dividido em dois volumes, parte de variados gêneros textuais (tentativa de romance, poemas, aforismos, crônicas sobre ciência, poesia, filosofia e religião, entrevistas, crítica de poesia e de romances), ou seja, de seus primeiros textos publicados no jornal paraense "Folha do Norte" (1946-1951), onde ele iniciou sua carreira de crítico de literatura, nas revistas "Encontro" (1948) e "Norte" (1952), e nos suplementos do "Jornal do Brasil", "O Estado de São Paulo" e "O Estado de Minas Gerais". Também são analisados os seus primeiros livros, "O mundo de Clarice Lispector" (1966) e "O dorso do tigre" (1969), que o consagram como um dos expoentes da crítica literária da segunda metade do século $X X$ no Brasil, principalmente dos autores que publicaram da década de 1940 em diante, a exemplo de Clarice Lispector, Guimarães Rosa e João Cabral de Melo Neto. A compilação de textos em periódicos, além de possibilitar a identificação das principais leituras de Benedito Nunes, incorporadas à concepção de sua crítica - como os filósofos cristãos, São Tomás de Aquino, Pascal e, especialmente, Søren Kierkegaard, constante nas análises do ensaísta -, permite traçar sua trajetória intelectual, particularmente como crítico literário. Nunes, posteriormente, vai acrescentar em suas análises as ideias de Jean-Paul Sartre e Martin Heidegger. Com relação a Heidegger, estudado por Nunes durante toda a sua vida, verifica-se a concepção ontológica da criação artística pela linguagem verbal, a qual, para o filósofo alemão, corresponde à fundação do ser pela palavra. $\bigcirc$ primeiro volume deste estudo contém a trajetória intelectual de Benedito Nunes, bem como a análise do material compilado nos periódicos e nos dois primeiros livros do crítico brasileiro, enquanto que o segundo volume contém uma amostra do material compilado.
The research analyzes the literary criticism of Benedito Nunes and is divided in two parts. It is based on a variety of textual genres (attempts to write novels, poems, aphorisms, chronicles on science, poetry and philosophy, interviews, criticism on poetry and novels). In other words, on the first texts of Nunes, published in the newspaper "Folha do Norte" (1946-1951), where he started the career as literary critic, in the magazines "Encontro" (1948) and "Norte" (1952), and in other Brazilian newspapers, such as "Jornal do Brasil", "O Estado de São Paulo" and "O Estado de Minas Gerais". Nunes' first books are also analyzed, "O mundo de Clarice Lispector" (1966) and "O dorso do tigre" (1969), for which he was acclaimed one of the exponents of literary criticism in the second half of the 20th century in Brazil, mainly of authors that published from the decade of 1940 on, namely, Clarice Lispector, Guimarães Rosa and João Cabral de Melo Neto. The compilation of texts published in newspapers enables the identification of the main readings of Benedito Nunes, which were incorporated to his work, such as the Christian philosophers, Saint Thomas Aquinas, Pascal and Søren Kierkegaard, who will be constant in the writings of Nunes. The compilation also makes possible to trace the intellectual trajectory of Nunes, especially as literary critic. He after added to his work the ideas of Jean-Paul Sartre and Martin Heidegger. Regarding Heidegger, who Nunes studied throughout his life, it is possible to consider the ontological conception of artistic creation by verbal language, which, according to the German philosopher, corresponds to the foundation of the self by the word. The first part of this research analyzes the intellectual trajectory of Benedito Nunes as well as the material compiled in newspapers and in his first books. The second part presents a sample of the compiled material. 